\title{
Biosynthesis of phospholipases and proteinases using clinical and environmental strains of Cryptococcus neoformans
}

\author{
- Pedro Henrique Magalhães Cardoso Institute of Biosciences, University of São Paulo, São Paulo, SP, \\ Brazil - Rennan Luiz Oliveira dos Santos School of Dentistry, University of São Paulo, São Paulo, SP, \\ Brazil • Ana Clara Souza School of Dentistry, University of São Paulo, São Paulo, SP, Brazil • Francisco de Assis Baroni Federal \\ Rural University of Rio de Janeiro, Rio de Janeiro, RJ, Brazil • Carina Domaneschi School of Dentistry, University of São Paulo, \\ São Paulo, SP, Brazil • Claudete Rodrigues Paula Graduate Program in Buccal Diagnosis, School of Dentistry, University of São \\ Paulo, São Paulo, SP, Brazil
}

ABSTRACT | Objective: To compare the production of enzymes (proteinases and phospholipases) among the clinical and environmental isolates of Cryptococcus neoformans, because researches with clinical and environmental isolates contribute to the understanding of the mechanisms involved in the control of these infections. Methods: In this research, 78 isolates of $C$. neoformans from clinical and environmental backgrounds were tested to demonstrate a possible associated phenotype and its virulence. Results: We observed that strains of clinical origin had a higher rate of phospholipase production than those of proteinase. There was no such differentiation among strains of environmental origin. Conclusion: These aspects emphasize the role of phospholipase in cases of $C$. neoformans infections of clinical origin, and may be a marker to evidence these species.

DESCRIPTORS | Cryptococcus; Cryptococcus neoformans; Enzymes; Virulence; Virulence Factors.

RESUMO | Biossíntese de fosfolipases e proteinases usando cepas de origem clínica e de origem ambiental do complexo Cryptococcus neoformans - Objetivo: Comparar a produção de enzimas (proteinases e fosfolipases) entre os isolados de origem clínica e de origem ambiental de Cryptococcus neoformans, uma vez que pesquisas com isolados de origem clínica e ambiental contribuem para a compreensão dos mecanismos envolvidos no controle destas infecções. Metodologia: Nesta pesquisa, 78 isolados de C. neoformans de origem clínica e ambiental foram testados para demonstrar um fenótipo possivelmente associado e sua virulência. Resultados: Observamos que as cepas de origem clínica tiveram uma taxa de produção de fosfolipase maior comparada à de proteinase. As cepas de origem ambiental não apresentaram tal diferenciação. Conclusão: Estes aspectos enfatizam o papel da fosfolipase em casos de infecções de $C$. neoformans de origem clínica e podem ser um marcador para evidenciar estas espécies.

DESCRITORES | Cryptococcus; Cryptococcus neoformans; Enzimas; Virulência; Fatores de Virulência.

CORRESPONDING AUTHOR | - Rennan Luiz Oliveira dos Santos Stomatology Department, School of Dentistry University of São Paulo • Av. Professor Lineu Prestes, 2227 São Paulo, SP, Brazi •05508-000 E-mail: rennan_475@hotmail.com

- Received January 3, 2018 • Accepted February 8, 2018

- Dol http://dx.doi.org/10.11606/issn.2357-8041.clrd.2018..133520 


\section{INTRODUCTION}

The Cryptococcus pathogenic complex is composed of heterothallic encapsulated yeasts that form basidiospores under experimental conditions. ${ }^{1}$ This pathogenic complex has two known species: Cryptococcus neoformans and Cryptococcus gattii. C. neoformans is the most frequent agent in cases of infection and mainly affects the face, neck and central nervous system. ${ }^{2,3}$ The lesions in the mouth appear as crateriform ulcers, which do not heal, with friable papillary erythematous plaques. ${ }^{3}$

Among the virulence factors already studied on C. neoformans, we can describe the production of enzymes, such as proteinase and phospholipase. ${ }^{4}$ Proteinases are produced by bacteria, protozoa and fungi acting on the cycle of infection of these microorganisms. They also play a role in protein catabolism and may act in degradative pathways, peptide hormone release, blood coagulation, cell death, and tissue differentiation. ${ }^{5}$

Phospholipases are produced and secreted by a variety of pathogenic microorganisms as part of their virulence. From the five classes of phospholipases produced by microorganisms, the phospholipase B (PLB) and phospholipase C (PLC) have been implicated in the virulence of Cryptococcus sp. ${ }^{6,7}$

Due to the increase in the number of immunocompromised patients, it has been observed an increase in the incidence of fungal infections, such as cryptococcosis. Research with clinical and environmental isolates has contributed to the understanding of the mechanisms involved in the control of these infections. ${ }^{8}$ The objective of this study was to compare the production of enzymes (proteinases and phospholipases) between the clinical and environmental isolates of $C$. neoformans, to highlight a possible biological marker (phenotype) that would be more intrinsically connected to the virulence of this yeast.

\section{MATERIAL AND METHODS}

A total of 78 strains of $C$. neoformans were studied, of which 36 were of clinical origin isolated from cerebrospinal fluid of patients with meningitis, and 42 were of environmental origin isolated from pigeon feces. These samples are kept in a mycelium, in Sabouraud dextrose agar and mineral oil, in freeze-drying at $-80^{\circ} \mathrm{C}$ in the Laboratory of Pathogenic Yeasts of the Department of Stomatology, Faculty of Dentistry, University of São Paulo.

The re-identification and confirmation of these strains were based on the methodology of Kurtzman, Fell ${ }^{9}$ and Kurtzman, Fell, Boekhout. ${ }^{10}$

The research of protease and phospholipase production was investigated in triplicate. The control strain producing these enzymes was $C$. albicans ICB-12A.

The technique proposed by Ruchel et al. ${ }^{11}$ was used to investigate the proteinase production. In each Petri dish containing the bovine serum albumin medium fraction $\mathrm{V}$, only one strain was seeded. Seeding was done in the central part of the middle surface. The plates were incubated at $32^{\circ} \mathrm{C}$ for up to 15 days. Proteinase production by the strain was verified by the presence of a clear zone of degradation around the colony (Figure 1). The proteolytic activity, called Pz, is expressed by calculating the ratio between the diameter of the colony (dc) and the diameter formed by the colony and the degradation zone (dcp).

For the phospholipase production tests, we used the technique proposed by Price et al. ${ }^{12}$ In each plate with culture medium, containing in the egg yolk composition, the sowing was done at a single central point on the surface of the culture medium. Plates were incubated at $32{ }^{\circ} \mathrm{C}$ for up to 15 days. Phospholipase-producing strains promote the formation of an area of opaque precipitation formed by calcium chloride around the colony (Figure 2). The value of phospholipase activity, 
called $\mathrm{Pz}$, was obtained by calculating the ratio between colony diameter (dc) and colony diameter and precipitation zone (dcp).

The results were analyzed based on index 3 (strongly positive) for the enzyme phospholipase in clinical and environmental strains using the chisquare statistical test of the BioEstat 5.0 program.

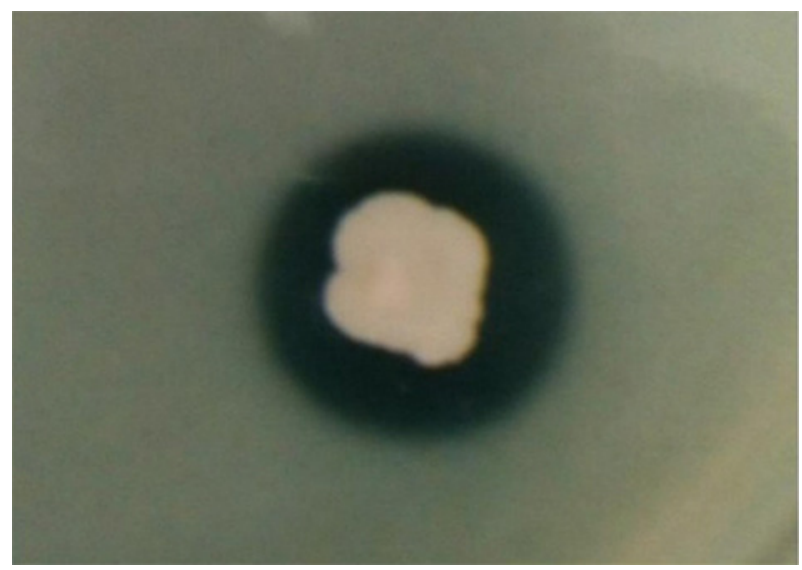

Figure 1 | Area of degradation of bovine serum albumin due to the action of the proteinase by the strain of $C$. neoformans.

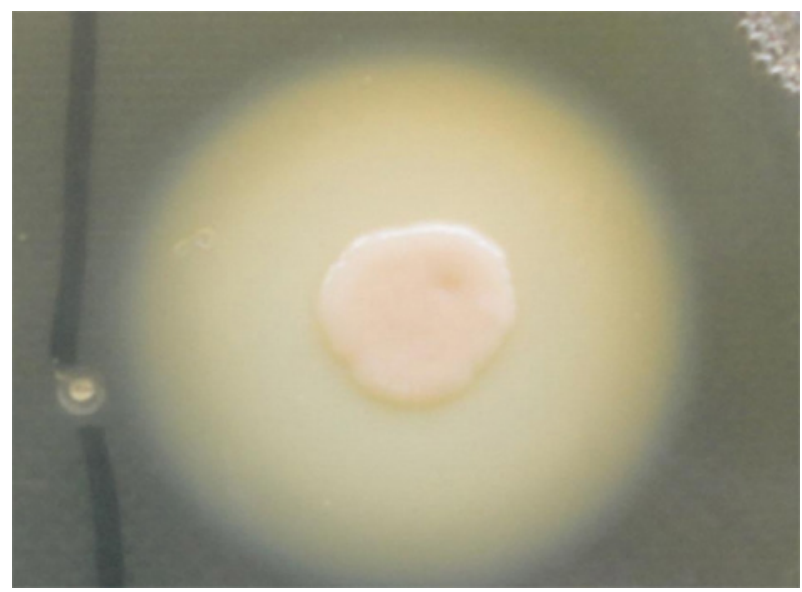

Figure 2 | Calcium chloride precipitation zone due to phospholipase by $\mathrm{C}$. neoformans strain.

\section{RESULTS}

After identification using biochemical and morphological methods, we observed that 36 (46\%) strains of clinical origin and 42 (54\%) of environmental origin were from $C$. neoformans species.
In relation to the proteinase enzyme in the strains of clinical origin, $19.5 \%(7 / 36)$ had index 3 (strongly positive), 50\% (18/36) had index 2 (positive) and 30.5\% (11/36) had index 1 (negative). Regarding the phospholipase production, $89 \%$ (32/36) had index $3,5.5 \%(2 / 36)$ had index 2 and $5 \cdot 5 \%(2 / 36)$ index 1 (Table 1$)$.

Table 1 | C. neoformans strains of clinical origin relating production index and virulence factors (proteinase and phospholipase).

\begin{tabular}{c|c|c|}
\multirow{2}{*}{ Production index * } & \multicolumn{2}{|c}{ Virulence factors } \\
\hline 3 & 19.5 & Phospholipase (\%) \\
\hline 2 & 50.0 & $89.0 * *$ \\
\hline 1 & 30.5 & 5.5 \\
\hline
\end{tabular}

* Production index: $(\mathrm{Pz}=1.0=$ Absence of enzymatic activity - (Index: 01); Pz $\geq 0.64<1.0$ = Positive Enzymatic activity (Index: 02); Pz <0.64 = Strongly positive activity - (Index: 03)

** significant for $p<0.05$ - Chi-square test performed in the BioEstat 5.0 program.

Total number of strains: 36 .

The strains of environmental origin, when studied in relation to proteinase production, showed that $38.1 \%(16 / 42)$ had index $3,35.7 \%$ (15/42) had index 2 and 26.2\% (11/42) had index 1. For phospholipase production, 52.4\% (22/42) had index 3 and 47.6\% (20/42) index 2 (Table 2).

Table 2 | C. neoformans strains of environmental origin relating production index and virulence factors (proteinase and phospholipase).

\begin{tabular}{|c|c|c|}
\hline \multirow{2}{*}{ Production index* } & \multicolumn{2}{|c|}{ Virulence factors } \\
\hline 3 & 38.1 & Phospholipase (\%) \\
\hline 2 & 35.7 & 52.4 \\
\hline 1 & 26.2 & 47.6 \\
\hline
\end{tabular}

* Production index: $(\mathrm{Pz}=1.0=$ Absence of enzymatic activity (Index: 01); $\mathrm{Pz} \geq 0.64<1.0=$ Enzymatic activity positive (Index: 02); $\mathrm{Pz}<0.64=$ Strongly positive activity - (Index: 03).

Total number of strains: 42 .

The statistical analysis of the results related to the index 3 (strongly positive) for the enzyme phospholipase between clinical and environmental strains was significant for the clinical strains ( $\mathrm{p}<0.05)$. 


\section{DISCUSSION}

In the investigation of proteinase production in strains of Cryptococcus neoformans, we obtained $19.5 \%$ of strong positivity in clinical strains and $38.1 \%$ of strong positivity in environmental strains.

Sánchez et al., ${ }^{13}$ carrying out studies with clinical isolates of the National Institute of Health of Bogotá, classified the in vitro activity of proteinase production in C. neoformans into high, medium and non-producing. Most of the strains had medium to high proteolytic activity, corroborating with the findings of our research.

On the other hand, Baroni ${ }^{4}$ verified that none of the environmental isolates from pigeon feces were producers of the enzyme, thus disagreeing with the findings of our study. Pereira,,${ }^{14}$ studying the production of proteinase by strains from environmental isolates of poultry feces marketed in Pet Shops in Rio de Janeiro, found that 96\% were strongly protease-producing.

Studies that compare proteinase production with clinical and environmental isolates of the Cryptococcus complex are rare. Regarding our findings, the higher productivity of protease (index 3 - strongly positive) due to the environmental strains can be explained by the protective role of this enzyme in adverse conditions of its ecological niche.

In this investigation, the production of phospholipase by strains of Cryptococcus neoformans was $88.9 \%$ with strong positivity in clinical strains, and $52.4 \%$ with strong positivity in environmental strains.

In the study conducted by Pereira, ${ }^{14} 57.12 \%$ of the environmental isolates were strongly positive and came from poultry feces marketed in Pet Shops in Rio de Janeiro. Sánchez et al. ${ }^{13}$, studying the clinical origin of $C$. neoformans strains, classified the in vitro activity of the enzyme phospholipase into medium and high, and $68.6 \%$ of C. neoformans strains were classified with high activity.
Baroni $^{4}$ found that $90.8 \%$ of strains isolated from pigeon feces were producers of phospholipase enzymes, $46 \%$ of which were strongly positive and $44.8 \%$ were positive. According to the author, considering the distribution of the different collection points of the samples, one must consider the possibility of risk of infection of passers-by and workers with these virulent strains.

Therefore, in this study, phospholipase was produced by the clinical and environmental strains and by the results of these two exoenzymes (proteinase and phospholipase), phospholipase was shown to be more important in the pathogenesis of cryptococcosis, because the percentage of the strongly positive index (89\%) in clinical strains was higher than the environmental ones (52.4\%).

According to Santagelo et al. ${ }^{15}$, the concentration of phospholipase B, lysophospholipase and lysophospholipase-transacylase produced by $C$. neoformans has an intrinsic relationship with virulence in mice.

In 2005, Santagelo et al. ${ }^{16}$ described for the first time the ELISA detection of antibodies to cryptococcal phospholipase B in serum of patients infected with C. neoformans and C. gattii. In this study, the authors provided the first confirmatory evidence of the in vitro production of cryptococcal phospholipase during human infection by $C$. neoformans and C. gattii.

\section{CONCLUSION}

Although enzymes, protease and phospholipase, are present in the clinical and environmental strains of $C$. neoformans, the high production of phospholipase by clinical strains was prominent and statistically significant. The strongly positive production of the phospholipase enzyme by clinical strains of $C$. neoformans is a new parameter to be studied as a marker related to the greater virulence of this agent. 


\section{ACKNOWLEDGMENTS}

We thank Maria Catarina de Almeida Lago for assistance with translation; your comments greatly improved our manuscript.

\section{REFERENCES}

1. Anaissie EJ, McGinnis MR, Pfaller MA. Clinical mycology. New York: Elsevier Health Sciences; 2009.

2. Lacaz CS, Porto E, Martins JEC, Heins-Vaccari EM, Melo NT. Tratado de micologia médica Lacaz. $9^{\text {a }}$ ed. São Paulo: Sarvier; 2002. 1104p.

3. Neville BW, Damm DD, Allen CM, Bouquot JE. Patologia oral e maxilofacial. $3^{\text {a }}$ ed. Rio de Janeiro: Elsevier; 2009. 972p.

4. Baroni FA. Ocorrência de Cryptococcus neoformans em excretas de pombos localizadas em torres de igrejas na cidade do Rio de Janeiro: fatores de virulência e sensibilidade aos antifúngicos [tese]. São Paulo: Instituto de Ciências Biológicas da Universidade de São Paulo; 2001.

5. Calderone RA, Fonzi WA. Virulence factors of Candida albicans. Trends Microbiol. 2001;9(7):327-35. doi: 10.1016/ So966-842X(01)02094-7.

6. Ghannoum MA. Potential role of phospholipases in virulence and fungal pathogenesis. Clin Microbiol Rev. 2000;13(1):122-43.

7. Siafakas AR, Wright LC, Sorrell TC, Djordjevic JT. Lipid rafts in Cryptococcus neoformans concentrate the virulence determinants phospholipase $\mathrm{B} 1$ and $\mathrm{Cu} / \mathrm{Zn}$ superoxide dismutase. Eukaryot Cell. 2006;5(3):488-98. doi: 10.1128/ EC.5·3.488-498.2006.

8. Dias ALT, Brigagão MRPL, Colepicolo P, Siqueira AM, Silva EG, Paula CR. Superoxide dismutase in Cryptococcus neoformans varieties gattii, grubii and neoformans. Mem Inst Oswaldo Cruz. 2006;101(1):107-9. doi: Soo7402762006000100021.

9. Kurtzman CP, Fell JW. The yeasts: a taxonomic study. 4th ed. Amsterdam: Elsevier; 1998. 1076p.

10. Kurtzman CP, Fell JW, Boekhout T. The yeasts: a taxonomic study. 5th ed. Amsterdam: Elsevier; 2011. 2354p.

11. Rüchel R, Tegeler R, Trost M. A comparison of secretory proteinases from different strains of Candida albicans. Sabouraudia. 1982;20(3):233-44.

12. Price MF, Wilkinson ID, Gentry LO. Plate method for detection of phospholipase activity in Candida albicans. Sabouraudia. 1982;20(1):7-14.

13. Sánchez A, Escandón P, Castañeda E. Determinación in vitro de la actividad de los factores asociados con la virulencia de aislamientos clínicos del complejo Cryptococcus neoformans. Rev Iberoam Micol. 2008;25(3):145-9.

14. Pereira JR. Isolamento e caracterização de Cryptococcus neoformans de excretas de aves colhidas em lojas de animais do município do Rio de Janeiro [dissertação]. Rio de Janeiro: Instituto de Veterinária, Universidade Federal Rural do Rio de Janeiro; 2006.

15. Santangelo RT, Nouri-Sorkhabi MH, Sorrell TC, Cagney M, Chen SC, Kuchel PW, et al. Biochemical and functional characterisation of secreted phospholipase activities from Cryptococcus neoformans in their naturally occurring state. J Med Microbiol. 1999;48(8):731-40. doi: 10.1099/00222615-48-8-731.

16. Santangelo RT, Chen SC, Sorrell TC, Wright LC. Detection of antibodies to phospholipase B in patients infected with Cryptococcus neoformans by enzyme-linked immunosorbent assay (ELISA). Med Mycol. 2005;43(4):335-41. 